\title{
Efektifitas Propolis Pada Perbaikan Histopatologi Hepar Mencit Betina yang Dipapar Logam Berat $\mathrm{Pb}$ Asetat
}

\section{Effectivity of Propolis on The Improvement of Liver Histophatology of Female Mice Exposed by Heavy Metal Pb Acetate}

\author{
Rachmani, S.D. ${ }^{1}$, Hestianah, E.P. ${ }^{2}$, Plumerastuti, H. ${ }^{3}$, Darsono, R. ${ }^{3}$ \\ Safitri, E. ${ }^{*}$
}

\author{
${ }^{1}$ Alumni Fakultas Kedokteran Hewan Universitas Airlangga, Surabaya, Indonesia \\ 2Departemen Anatomi Veteriner,Fakultas Kedokteran Hewan Universitas Airlangga, Surabaya, \\ Indonesia \\ 3Departemen Patologi Veteriner,Fakultas Kedokteran Hewan Universitas Airlangga, Surabaya, \\ Indonesia \\ ${ }^{4}$ Departemen Reproduksi Veteriner,Fakultas Kedokteran Hewan Universitas Airlangga, Surabaya, \\ Indonesia \\ *e-mail: rma_fispro@yahoo.com
}

\begin{abstract}
ABSTRAK
Tujuan penelitian ini adalah untuk mengetahui pengaruh propolis terhadap gambaran histopatologi hati pada mencit (Mus musculus) betina yang terpapar timbal asetat. Subjek penelitian adalah 25 ekor mencit galur BALB / C dengan berat rata-rata 25-35 gram berumur 8 minggu, dibagi menjadi 5 kelompok perlakuan dan terdiri dari 5 ekor per kelompok. Kelompok K diberi larutan Tween 80 dengan dosis 0,5 mg / kg BB selama 20 hari berturut-turut. Kelompok $\mathrm{K}+$ yang hanya diberi timbal asetat dengan dosis $10 \mathrm{mg} / \mathrm{kg}$ BB secara oral selama 10 hari. P1, P2, P3 diberikan larutan timbal asetat $10 \mathrm{mg} / \mathrm{kg}$ BB secara oral selama 10 hari. 10 hari berikutnya diberikan propolis dengan dosis P1 $200 \mathrm{mf} / \mathrm{kg} \mathrm{BB}, \mathrm{P} 2400 \mathrm{mg} / \mathrm{kg}$ BB, P3 $800 \mathrm{mg} / \mathrm{kg}$ BB. Pada hari ke 21 mencit dibedah untuk mengamati tingkat kerusakan yang terjadi. Semua data dilakukan menggunakan uji statistik dengan uji Kruskal Wallis dan jika terdapat perbedaan yang nyata antar kelompok perlakuan $(\mathrm{p}<0,05)$ maka dilanjutkan uji Mann-Whitney. Hasil penelitian diperoleh bahwa propolis lebah dapat memperbaiki kerusakan sel hati mencit betina yang terpapar timbal asetat. Peningkatan dosis propolis tidak efektif dalam memperbaiki kerusakan sel hati mencit betina yang terpapar timbal asetat.
\end{abstract}

Kata kunci: Propolis, timbal asetat, histopathologi hati, mencit betina

\begin{abstract}
The purpose of this study was to find out the effect of propolis on histopathology images of hepatic mice (Mus musculus) of female exposed by lead acetate. The subjects were 25 mice of BALB/C strain with average weight 25-35 gram and 8 weeks old, divided into 5 treatment groups and consist of 5 mice per group. The K- group was given Tween 80 solution at a doses of $0.5 \mathrm{mg} / \mathrm{kg}$ BW for 20 consecutive days. The K+ group, which was given only lead acetate at a doses of $10 \mathrm{mg} / \mathrm{kg}$ BW orally for 10 days. P1, P2, P3 were given $10 \mathrm{mg} / \mathrm{kg}$ BW lead acxetate solution orally for 10 days. The following 10 days were given propolis with doses of P1 $200 \mathrm{mf} / \mathrm{kg} \mathrm{BW}, \mathrm{P} 2400 \mathrm{mg} / \mathrm{kg} \mathrm{BW}, \mathrm{P} 3$ $800 \mathrm{mg} / \mathrm{kg} \mathrm{BW}$. On the $21^{\text {th }}$ days the mice were dissected to observe the extent of the damage. All data were performed using statistical test with Kruskal Wallis test and if there was a marked difference between treatment groups $(\mathrm{p}<0.05)$, then the Mann-Whitney test was followed. The
\end{abstract}


results obtained that bee propolis can repair hepatic cell damage in mice of female exposed by lead acetate. Increased dose of propolis is ineffective in repairing hepatic cell damage in mice of female exposed by lead acetate.

Keywords: Propolis, lead acetate, liver histopathology, female mice

\section{PENDAHULUAN}

Peningkatan proses industrialisasi

berakibat pada peningkatan pencemaran berbagai logam berat. Hal ini dikarenakan pabrik industri yang dibangun dengan tidak mengikuti sistem instalasi pengolahan air dan limbah (IPAL) yang memadai, akan berakibat pada peningkatan limbah yang dibuang ke lingkungan. Salah satu limbah logam dari banyak jenis yang menjadi pencemar lingkungan adalah timbal ( $\mathrm{Pb}$ asetat) (Wardhayani, 2006). Timbal dapat masuk dalam tubuh mahluk hidup melalui saluran pencernaan (gastrointestinal), saluran pernafasan (inhalasi), dan penetrasi melalui kulit (topikal), baik secara langsung maupun tidak langsung. Makanan dan minuman dapat terpapar timbal yang berasal dari kontaminasi pipa, solder, kran dan kontamunasi kaleng minuman dan makanan yang mengandung timbal (Dedy, 2008).
Toksisitas $\mathrm{Pb}$ terutama memberikan dampak yang berat pada organ-organ penting pada mahluk hidup misalnya pada hepar dan ginjal (Darmono, 2001). Hepar merupakan organ tubuh terbesar dan organ metabolism yang paling kompleks di dalam tubuh. Organ ini terlibat dalam metabolism zat makanan serta Sebagian besar obat toksikan. Menurut Santosa (2005) apabila senyawa racun yang masuk terlalu besar sehingga bersifat toksis pada hepar, maka akan menimbulkan degenerasi jaringan hepar, bahkan sampai terjadi nekrosis yang dapat merusak jaringan hepar, Hepar berperan dalam melakukan proses metabolisme dan detoksifikasi untuk menetralkan senyawa yang bersifat racun dalam tubuh, Adapun mekanisme kerusakan hepar oleh $\mathrm{Pb}$ dapat terjadi akibat meningkatnya radikal bebas dan penurunan kemampuan system antioksidan tubuh sehingga memicu stress oksidatif (Gurer and Ercal, 2000). Untuk melindungi hepar dari 
keruskan tersebut, maka diperlukan zat yang mampu melawan radikal bebas akibat paparan $\mathrm{Pb}$, yaitu dengan antioksidan (Adams and Angulo, 2006).

Kandungan antioksidan yang tinggi terdapat pada propolis. Komponen utama dari propolis adalah flavonoid dan asam fenolat, termasuk Caffeic Acid Phenetyl Ester (CAPE). Penelitian di Jepang menunjukkan bahwa kandungan CAPE yang ada di dalam propolis mempunyai aktivitas antioksidan yang tinggi yang dapat meningkatkan ekspresi glucose-6phosphate dehydrogenese (G6PD) yang didapat dari ekspresi gen antioksidan, lebih kuat dibandingkan vitamin E. CAPE mempunyai aktivitas antioksidan 4-6 kali lebih kuat terhadap oksidan seperti $\mathrm{H}_{2} \mathrm{O}_{2}$ dan radikal bebas dibandingkan vitamin $\mathrm{C}$ dan $\mathrm{N}$ acetyl-cystein (NAC) (Nakajima, 2009).

Propolis terbukti memiliki efek hepatoprotektor yang baik, namun belum diketahui pengaruh pemberian propolis terhadap gambaran histopatologi hepar mencit (Mus musculus) betina yang dipapar logam berat $\mathrm{Pb}$ asetat.

\section{MATERI DAN METODE}

Penelitian ini menggunakan 25 ekor mencit (Mus musculus) betina strain BALB C dengan berat rata-rata 25-30 gram dan berumur 8 minggu yang diperoleh dari Pusat Veteriner Farma (Pusvetma), Surabaya, Jawa Timur. Kemudian dipelihara dalam kondisi yang sama, diberikan pakan harian berbentuk pellet serta air minum yang diberikan secara $a d$ libitum.

Sebelum penelitian dilakukan, mencit betina diadaptasikan selama 7 hari dan diberikan pakan pellet serta air minum secara ad libitum setiap hari.

\section{Persiapan bahan timbal asetat dan pembuatan propolis}

Bahan yang digunakan dalam penelitian ini adalah timbal asetat $\left[\mathrm{Pb}\left(\mathrm{C}_{2} \mathrm{H}_{3} \mathrm{O}_{2}\right)_{2}\right]$. Tablet propolis lebah (CC Pollen Co, USA, PT. Harmoni Dinamik Indonesia Jakarta) dihaluskan sampai halus dan homogen meggunakan mortar dan stamper. Setelah itu ditambahkan dengan tween 80 sebanyak $1 \%$ sebagai suspensator.

\section{Prosedur Penelitian}


Mencit diberikan perlakuan dengan propolis dan timbal asetat secara per oral menggunakan $1 \mathrm{ml}$ tuberculin sekali pakai selama 20 hari. Perlakuan tersebut dijelaskan sebagai berikut:

K (-) : Kelompok kontrol, hanya hanya diberi Tween 80 sebanyak $0.5 \mathrm{ml} /$ ekor/hari selama 20 hari

$\mathrm{K}(+) \quad$ Larutan $\mathrm{Pb}$ asetat 10 $\mathrm{mg} / \mathrm{kg} / \mathrm{BB}$ selama 10 hari

$\mathrm{P}(1) \quad$ : Larutan $\mathrm{Pb}$ asetat 10 $\mathrm{mg} / \mathrm{kg} / \mathrm{BB}$ selama 10 hari + propolis $200 \mathrm{mg} / \mathrm{kg}$ BB selama 10 hari berikutnya

$\mathrm{P}(2)$ : Larutan $\mathrm{Pb}$ asetat 10 $\mathrm{mg} / \mathrm{kg} / \mathrm{BB}$ selama 10 hari + propolis $400 \mathrm{mg} / \mathrm{kg}$ BB selama 10 hari berikutnya

$\mathrm{P}(1)$ : Larutan $\mathrm{Pb}$ asetat 10 $\mathrm{mg} / \mathrm{kg} / \mathrm{BB}$ selama 10 hari + propolis $800 \mathrm{mg} / \mathrm{kg}$ BB selama 10 hari berikutnya

Setelah 24 jam dari pemberian propolis terakhir, mencit dikorbankan denga metode dislocation cervicalis, kemudian dilakukan pengambilan organ hepar mencit dan dimasukkan dalam Neutral Buffered Formalin 10\%. Perubahan yang diamati adalah :

$$
\begin{aligned}
& \text { Degenerasi } \quad \text { kelainan yang } \\
& \text { menyebabkan } \\
& \text { perubahan pada } \\
& \text { sitoplasma sel berupa } \\
& \text { pembengkakan, } \\
& \text { akumulasi air dan } \\
& \text { kekeruhan sitoplasma. }
\end{aligned}
$$

Nekrosis : kematian sel dari jaringan tubuh yang masih hidup dan ditandai dengan

Adanya perubahan pada inti sel berupa piknotis, karioreksis dan kariolisis.

Hal ini terjadi Ketika tidak ada cukup darah mengalir ke jaringan baik karena cidera, radiasi atau bahan kimia.

Pemeriksaan preparat histopatologi hepar dilakukan dengan mengamati lesi dengan vena sentralis berada ditengah-tengah 
lapang pandang dan menggunakan mikroskop cahaya pembesaran 400x. Kemudian dilakukan pem \nilaian derajat kerusakan hepar. Penilaian derajat kerusakan hepar menggunakan metode scoring berdasarkan persen terjadinya degenerasi dan nekrosis (Brunt el al., 1999) (Tabel 1).

\section{Tabel 3.1. Skor penilaian derajat histopathologi sel hepar}

\begin{tabular}{lcc}
\hline \multicolumn{1}{c}{ Derajat } & Degenerasi & Nekrosis \\
\hline Tidak ada & 0 & 0 \\
Minimal $(0-25 \%)$ & 1 & 1 \\
Ringan $(25-50 \%)$ & 2 & 2 \\
Sedang $(50-75 \%)$ & 3 & 3 \\
Berat $(75-100 \%)$ & 4 & 4 \\
\hline
\end{tabular}

\section{Pengamatan gambaran mikroskopik hepar}

Pemeriksaan sediaan hepar yang sudah diwarnai dengan pewarnaan Hematoxylin Eosin (HE) menggunakan mikroskop cahaya Olympus dengan perbesaran 400x.

\section{Analisis Data}

Data yang diperoleh berupa skor nilai gambaran histopatologi yang meliputi degenerasi dan nekrosis hepatosit mencit yang disusun dalam bentuk table kemudian dilakukan analisis statistik. Analisis data dilakukan uji statistic dengan menggunakab uji Krukal Wallis dan bila terdapat perbedaan yang nyata diantara kelompok perlakuan $(p<0.05)$, maka dilanjutkan dengan uji MannWhitney. Seluruh analisis tersebut dikerjakan dengan program computer SPSS 18.00 for Windows.

\section{HASIL}

Hasil pemeriksaan histopatologi hepar mencit (Mus musculus) betina sebagai hewan coba dalam penelitian berdasarkan pengamatan degenerasi dan nekrosis hepar ini dapat dilihat pada Tabel 2. 
Tabel 2. Nilai Rerata Tingkat Degenerasi dan Nekrosis Hepatosit

\begin{tabular}{|c|c|c|}
\hline Perlakuan & $\begin{array}{l}\text { Reratan } \pm \text { SD } \\
\text { Degenerasi }\end{array}$ & $\begin{array}{l}\text { Rerata } \pm \text { SD } \\
\text { Nekrosis }\end{array}$ \\
\hline $\begin{aligned} \text { K- = } & \text { Kelompok kontrol, hanya hanya diberi Tween } 80 \\
& \text { sebanyak } 0.5 \mathrm{ml} / \text { ekor/hari selama } 20 \text { hari }\end{aligned}$ & $3.00^{\mathrm{a}} \pm 1.32$ & $6.00^{a} \pm 0.43$ \\
\hline $\mathrm{K}+=$ Larutan $\mathrm{Pb}$ asetat $10 \mathrm{mg} / \mathrm{kg} / \mathrm{BB}$ selama 10 hari & $23.0^{\mathrm{d}} \pm 1.45$ & $23.0^{\mathrm{d}} \pm 0.48$ \\
\hline $\begin{aligned} \mathrm{P} 1= & \text { Larutan } \mathrm{Pb} \text { asetat } 10 \mathrm{mg} / \mathrm{kg} / \mathrm{BB} \text { selama } 10 \text { hari } \\
& + \text { propolis } 200 \mathrm{mg} / \mathrm{kg} \text { BB selama } 10 \text { hari berikutnya }\end{aligned}$ & $15.7 \mathrm{c} \pm 1.22$ & $17.6^{c} \pm 0.52$ \\
\hline $\begin{aligned} \mathrm{P} 2= & \text { Larutan } \mathrm{Pb} \text { asetat } 10 \mathrm{mg} / \mathrm{kg} / \mathrm{BB} \text { selama } 10 \text { hari } \\
& + \text { propolis } 400 \mathrm{mg} / \mathrm{kg} \text { BB selama } 10 \text { hari berikutnya }\end{aligned}$ & $15.3^{c} \pm 1.08$ & $12.7^{b} \pm 0.55$ \\
\hline $\begin{aligned} \mathrm{P} 3= & \text { Larutan } \mathrm{Pb} \text { asetat } 10 \mathrm{mg} / \mathrm{kg} / \mathrm{BB} \text { selama } 10 \text { hari } \\
& + \text { propolis } 800 \mathrm{mg} / \mathrm{kg} \text { BB selama } 10 \text { hari berikutnya }\end{aligned}$ & $8.00^{\mathrm{b}} \pm 1.47$ & $6.00^{a} \pm 0.48$ \\
\hline
\end{tabular}

$\overline{\text { Superskrip yang berbeda pada kolom yang sama memperlihatkan perbedaan yang nyata }(\mathrm{P}<0,05)}$

\section{DISKUSI}

Berdasarkan hasil penelitian, pada kelompok K- yang tidak terpapar $\mathrm{Pb}$ asetat dan tanpa pemberian propolis, kondisi hepar normal karena sel hepatosit tidak mengalami jejas, inti sel Nampak berwarna biru dan sitoplasma Nampak berwarna keunguan karena bersifat eosinofilik. Kelompok perlakuan $\mathrm{K}+$ yang tanpa diberikan propolis namun dipapar logam berat $\mathrm{Pb}$ asetat 10 $\mathrm{mg} / \mathrm{kgBB}$ menunjukkan kelainan patologi degenerasi tertinggi skor 4 artinya degenerasi dan nekrosis terjadi 75\%-100\% dari seluruh lapangan pandang dibandingkan dengan kelompok perlakuan lainnya. Timbal yang masuk ke dalam tubuh melalui saluran pencernaan akan diabsorbsi oleh usus untuk dimetabolisme di hepar. Vena porta membawa darah deoksigenasi dan zat toksik timbal yang diabsorbsi dari usus. Cabang dari vena porta membawa darah terebut ke sinusoid yang kemudian diiterima oleh sel hepar. Timbal 
dalam sel hepatosit dapat menginduksi pembentukan radikal bebas dan menurunkan kemampuan sistem antioksidan tubuh sehingga terjadi stress oksidatif. Menurut penelitian Jin et al. (2008) mencit yang diberi logam berat $\mathrm{Pb}$ asetat dosis $10 \mathrm{mg} / \mathrm{kg} \mathrm{BB}$ secara oral dapat memicu timbulnya stress oksidatif. Stress oksidattif memicu pembentukan radikal bebas yaitu Reactive Oxygen Species (ROS) yang dapat bereaksi den menyebabkan kerusakan pada banyak molekul di dalam sel. Perusakan sel akibat ROS didahului oleh kerusakan membrane sel antara lain mengubah fluiditas, struktur dan fungsi membrane sel (Sipos et al., 2003). Radikal bebas berikatan dengan lipid dari membrane sel hepatosit membentuk peroksidasi lipid. Konsekuensi penting dari peroksidasi lipid adalah meningkatnya permeabilitas membrane yang dapat menggaggu proses pompa ion $\mathrm{Ca}^{2+}$ dan hambatan terhadap proses pompa ion $\mathrm{Na}+$ dan $\mathrm{K}+$ di dalam sel sehingga terjadi degenerasi pada sel karena gangguan hemostasis. Keadaan sel yang mengalami gangguan tersebut dapat menyebabkan keadaan di dalam sel lebih pekat dan bersifat hipotonis sedangkan keadaan ekstraseluler menjadi hipertonis sehingga cairan yang berada pada ekstraseluler akanmmasuk ke dalam intraseluler dan menyebabkan gangguan patologi yang biasa disebut degenerasi hidrofik. Secara umum degenerasi dikarenakan adanya penurunan kemampuan system pompa ion $\mathrm{Na}+$ dalam sel yang menyebabkan pembengkakan sel dan degenerasi keruh (Kresnasari dkk., 2014).

Pada kelompok P1 yang diberi propolis $200 \mathrm{mg} / \mathrm{kgBB}$ tampak histopatologi hepar berupa degenerasi hidrofik, yang merupakan jejas yang reversible. Peran propolis pada P1 telah menunjukan perbaikan jejas sel, namun masih belum mencapai keadaan normal. Perubahan yang terjadi adalah sel hepatosit Nampak membengkak berisi cairan, inti sel masih terlihat jelas dan jaringan hepar masih dapat dikenali. Sel hepatosit masih Nampak membesar dan mendesak sinusoid. Sitoplasma sel tampak keruh dan pucat. Hal tersebut terjadi karena jumlah zar aktif yang berperan 
sebagai antioksidan dalam propolis pada dosis tersebut masih belum cukup efektif untuk melawan radikal bebas.

Pada kelompok perlakuan P2 yang diberikan propolis $400 \mathrm{mb} / \mathrm{kg}$ BB juga masih terlihat adanya degenerasi hidrofilik disebabkan terganggunya metabolism energi dalam sela tau karena cedera pada membrane sel sehingga sel tidak mampu memompa ion $\mathrm{Na}+$ yang cukup (Resaang, 1994) tetapi jumlahnya tidak sebanyak kelompok perlakuan sebelumnya. Kelompok perlakuan P3 yang diberikan propolis $800 \mathrm{mg} / \mathrm{kg} \mathrm{BB}$ terjadi degenerasi ringan. Peran propolis pada konsentrasi initelah dapat memperbaiki jejas sel yang reversible, dikarenakan keadaanya hamper mencapai normal. Propolis mengandung flavonoid. Senyawa flavonoid berperan dalam aktivitas antioksidan, yaitu dengan menghambat dihasilkannya agen oksidatif seperti ROS oleh sel darah perifer, atau dengan menghambat paparan osidatif dalam tubuh yang melindungi lipid protein agar tidak berubah menjadi lipid peroksida. Kedua mekanisme ini membuat flavonoid memiliki beberapa efek, diantaranya menghambat peroksidase lipid, menahan kerusakan jaringan oleh radikal bebas (Krisnatuti dan Yenrina, 2005).

Pada kelompok K+ yang hanya dipapar $\operatorname{logsm}$ berat $\mathrm{Pb}$ asetat $10 \mathrm{mg} / \mathrm{kg}$ BB mengalami nekrosis paling parah dengan nilai skor 4, artinya nekrosis terjadi pada $75 \%-100 \%$ dari seluruh lapangan pandang, terjadi kematian sel yang bersifat irreversible yaitu kariolisis. Inti sel menjadi hilang sehingga pada gambar tampak sebagai sel yang kosong (Wulandari, 2006). Apabila darah dari vena porta banyak membawa racun atau toksin, maka zona pertama paling dekat dengan sumber pasokan darah yang pertama kali terkena zat toksik tersebut sehingga kerusakan sel paling banyak ditemukan pada sekitar portalis (Arimbi dkk., 2013).

Pada kelompok perlakuan K- yang tanpa dipapar logam berat $\mathrm{Pb}$ asetat dan propolis, $\mathrm{P} 1$ yang diberi propolis $200 \mathrm{mg} / \mathrm{kg}$ BB dan P2 yang diberi propolis $400 \mathrm{mg} / \mathrm{kg} \mathrm{BB}$ masih terlihat adanya nekrosis, tetapi dalam jumlah yang sedikit, tidak merata, bahkan dibeberapa 
tempat nekrosis tidak terjadi sehingga skor yang di dapat adalah 0. Pada kelompok perlakuan P3 yang diberi propolis $800 \mathrm{~g} / \mathrm{kg} \mathrm{BB}$ telah dapat memperbaiki jejas sel sama halnya dengan antibiotik sehingga kematian sel yang bersifat irreversible dapat dicegah.

Propolis dapat berfungsi memperbaiki kondisi patologi dari bagian tubuh yang sakit, bekerja sebagai antioksidan dan antibiotik serta meningkatkan sistem kekebalan tubuh baik humoral maupun seluler karena mengandung flavonoid sekitar 15\% (Krell, 1996). Flavonoid merupakan antioksidan dan antibiotic yang berfungsi menguatkan Dan mengantisipasi kerusakan pada pembuluh darah serta bahan aktif yang berfungsi sebagai anti radang dan antivirus. Daya antioksidan menggambarkan besarnya potensi propolis untuk berperan sebagai antioksiidan. Anti oksidan yang ada dapat meredam dampak negative dari oksidan dengancara memberikan elektronya pada oksidan, antioksidan tersebut mampu mencegah dan meregenerasi kerusakan sel akibat radikal bebas (Widjaja, 1997).

\section{KESIMPULAN}

Disimpulkan bahwa pemberian propolis memberikan pengaruh yang dapat memperbaiki sel hepatosit dari kerusakan akibat paparan logam berat $\mathrm{Pb}$ asetat. Pemberian propolis dengan dosis $800 \mathrm{mg} / \mathrm{kg}$ BB paling baik memperbaiki sel hepatosit dari kerusakan akibat logam berat $\mathrm{Pb}$ asetat.

\section{DAFTAR PUSTAKA}

Adams L.A and P. Angulo. 2006. Treatment of non alcoholic fatty liver disease. Postgrad Med. 82: 315-22.

Arimbi, A. Azmijah, R. Darsono, H. Plumerastuti, T.V. Widiyatno, D. Legowo .2013. Buku Ajar Patologi Umum Veteriner. Airlangga University Press. Surabaya. 9-10.

Darmono. 2001. Lingkungan Hidup dan Pencemaran. Hubungan dengan Toksikologi Senyawa Logam. Penerbit Universitas Indonesia (UI Press). 109, 112, 140.

Dedy, S. 2008. Pengaruh Proteksi Vitamin C terhadap enzim Transminaze dan gambaran histopatologi hepar mencit 
yang dipapar plumbum (Tesis) Sumatra

Utara. Universitas Sumatra Utara.

Jin X, L. Ling-Jun, W. Chen, W. Xiao-Feng, F. Wen-Yu and X. Li-Hong. 2008. Lead induces oxidative oxidative strass, DNA damage and alteration of p53, Bax and Bcl-2 expression in mice. Food and Chem Tox. 46: 1488-1494.

Krell, R. 1996. Value added product from beekeeping.

http://www.fao.org/docrep/w0076e

Krisnasari, D, K. Diah, S. Hidayat, R.B.A Viva .2014. Efek propolis terhadap fungsi dan perlemakan hati tikus putih (Rattus norvegicus) model Hiperkolesterolemia. Jurusan Kedokteran.FKIK. Universitas Jendral Soedirman. Purwokerto.

Krisnatuti, D dan S. Yenrina .2005. Menyiapkan makanan pendamping ASI. Pustaka Swara. Jakarta.

Lu, F.C. 1995. Toksikologi dasar, azas, orga sasaran dan penilaian resiko. Edisi Kedua. Jakarta. Penerbit UI. Hal. 224-235. Nakajima, Y .2009. Comparison of bee products based on assays of antioksidant capacities. BMC Complementary and Alternative Medicine.

Ressang, M.D. 1984. Patologi khusud veteriner. Edisi kedua. Team Leader IFAD Project : Bali cattle disease investigation unit. Denpasar. Bali 45-46.

Sipos, P, K. Szentmihalyl, E. Feher, M. Abaza, M. Szilsgyl and A. Blazovics .2003. Some effects of lead contamination on liver and gallbladder bile. Acta Biol Szegediensia. 47()1-4): 139-142.

Wardhayani, S. 2006. Analisis resiko pencemaran bahan toksik timbal $(\mathrm{Pb})$ pada sapi potong di tempat pembuangan akhir (TPA) sampah jatibarang (Tesis). Fakultas Kesehatan Lingkungan Universitas Diponegoro.

Widjaya, S. 1997. Antioksidan pertahanan tubuh terhadap efek oksidan dan radikal bebas. Maj. Ilm Fak Kedok. Usakti. 16(1): 162. 